\title{
Thin gruel in the face of the national child obesity epidemic
}

Published at www.cmaj.ca on Oct. 28

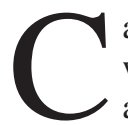

anada's child obesity epidemic will never be stemmed without a national school food program and a national child nutrition strategy, complete with restrictions on junk food advertising and clear nutrition standards and guidelines, according to health advocates at an international food conference.

Canada remains one of the few G8 nations without a national child nutrition strategy and a school food program, New Democrat Member of Parliament Olivia Chow told the Championing Public Health Nutrition 2010 conference on Oct. 26 in Ottawa, Ontario.

"We know 12-year-old boys are 14 pounds heavier than they were 20 years ago, and girls are 11 pounds heavier. We know that one in four children aged 6 to 11 are overweight or obese. We know more than a quarter of our teenagers are overweight and half, especially girls, skip breakfast," she said. "So why is it in Canada we have no federal policy, no funding, no coordination and no evaluation?"

As with many aspects of public health, the federal government appears content to defer to the provinces and as a result, nutrition guidelines for food sold in schools are patchwork in nature, the conference was told. British Columbia, Nova Scotia and New Brunswick have mandatory standards that prohibit trans fats while limiting sugar and sodium. Quebec has banned deep-fried foods and soft drinks in high schools. Ontario schools will implement a new food and beverage policy by September 2011.

Other provinces and territories have voluntary standards or, in the case of the Northwest Territories and Nunavut, no standards at all.

Despite provincial and volunteer efforts in all parts of the country, only $10 \%$ to $15 \%$ of Canadian children have access to school meals, Chow said. "That percentage is terrible."

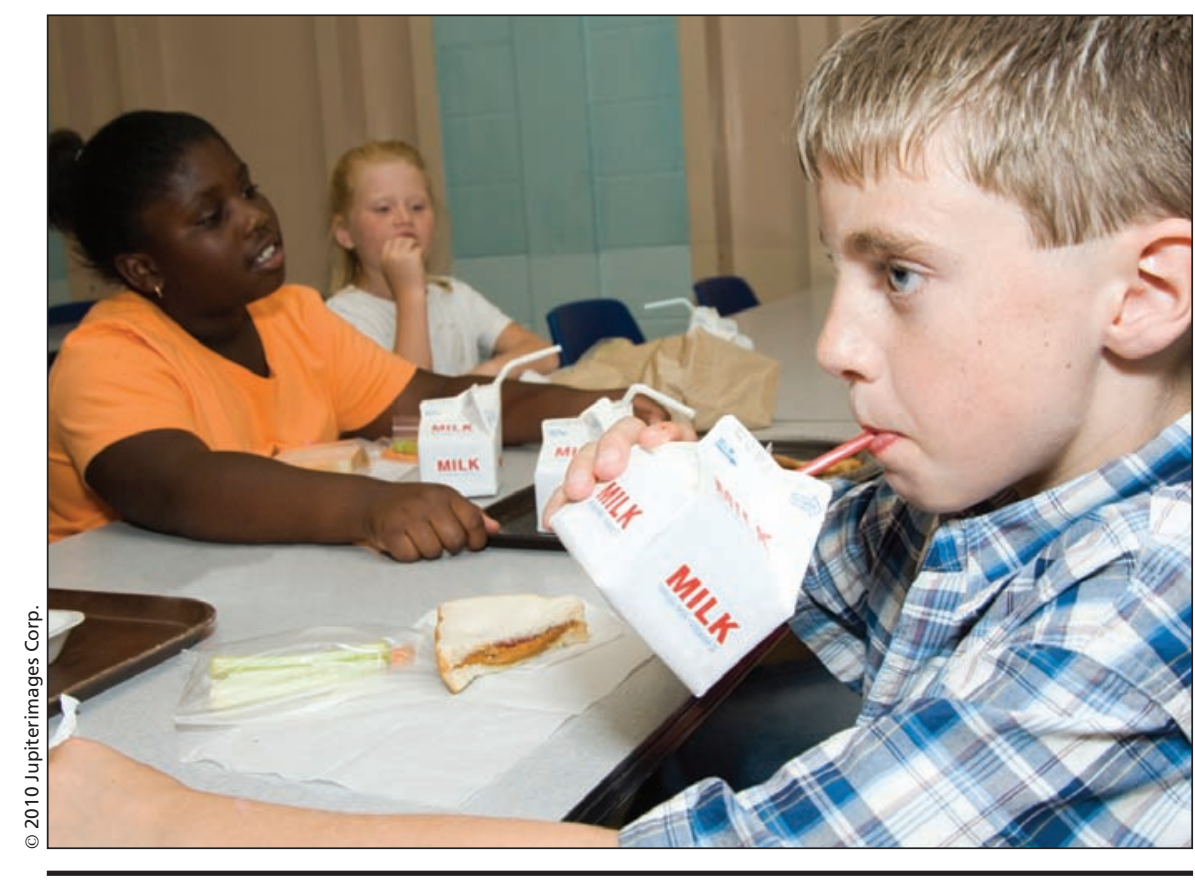

A national school food program should be universal, free and focused on wholesome foods, experts say.

By contrast, the United States, Finland, Sweden, Japan and the United Kingdom, have long had national school food programs in place. In Finland, where a national program has been running since 1948 , roughly $95 \%$ of children receive "decent" meals in schools, said Chow. In Sweden, $85 \%$ of children have access to school meals, while "even Vietnam and China have national food programs."

The benefits of a national school food program and standards are clear, says Mary McKenna, professor of kinesiology at the University of New Brunswick in Fredericton. They've been shown to encourage healthier eating, improve concentration and academic performance, and lower absenteeism.

Chow noted that there are also mental health benefits, as well as broader economic advantages to the community, including bolstered support for farmers who benefit when schools buy food locally.

A national child nutrition program should be universal, free and focus on wholesome foods, said McKenna. It should also promote a "shared experience" around food, in which students have enough time and somewhere comfortable to eat their food together, as opposed to sitting on the floor in gyms or hallways.

The arguments echoed those made by groups such as Breakfast for Learning and the Centre for Science in the Public Interest in 2007 when they called for healthy breakfasts, lunches and snacks to be made available to all Canadian children under 18 , national nutrition standards and federal funding to expand existing school food programs.

But Prime Minister Stephen Harper's Conservative government has maintained that the "design and delivery of social programs and services" is a provincial responsibility (http://cspinet .org/canada/pdf/federalfinanceminister reply.pdf).

Advertising to children, however, falls under federal jurisdiction, several delegates noted.

One obstacle in implementing pro- 
grams without national standards or funding is combating the influence of food marketing with limited resources, McKenna said. "The notion of giving the students a choice of food, educating them and then hoping they'll make the right choice isn't working. We still have this eating out frame of reference in school cafeterias, and what do you get when you eat out? Pizza."

A recent global study found Canadian kids are targeted by more television junk food advertisements than kids in 10 other countries. Children in Greece were exposed to the most food and beverage ads (nine per hour) compared with those in Canada (seven per hour). However, $80 \%$ of ads seen by Canadian kids were for foods high in fat and sugar, compared to only $65 \%$ of those in Greece. (Am J Public Health 2010; 100[9]:1730-1236)

Banning such ads would protect children and bolster child nutrition programs, said Chow. "Quebec did it in 1980 and kids there are healthier in general than others outside the province."

Quebec is the only province in Canada that prohibits all advertising to children under the age of 13 , although a recent national survey found $82 \%$ of respondents from across the country would like limits placed on the marketing of unhealthy foods to children (www.cqpp.qc.ca/fr/salle -de-presse/communiques-et-publications /89/massive-support-by-canadians-for -government-intervention-in-the-fight -against-the-obesity-epidemic). Other countries, such as Sweden, have also imposed restrictions on advertising to children.

There's mounting global criticism from industry, however, that such restrictions could impinge on constitutional rights such as freedom of expression, Amandine Garde, a senior lecturer in the department of law at the University of Durham in England, told delegates.

Schools, too, need to think about the messages they send students by providing certain foods, said McKenna. "If we're selling baked chips over regular chips and the kids think their school provides healthy options, they're going to get the message that baked chips are healthy."

Schools should also consider placing healthy foods close to cash registers, at eye level and in attractive displays, she said.

Another reason why healthy food policies may not be hitting their mark is that children are seldom involved in or adequately informed about changes to school menus, said McKenna. If kids don't understand a policy, they may "take their money and forks elsewhere."

Across Canada, school catering companies have reported sales losses in regions where unhealthy foods have been banned, McKenna said. That can put schools under financial pressure, particularly where they share profits, she added. "One principal said to me that they needed the chocolate bar fundraising campaigns back because it's simple, easy and the children were only selling the candy, not eating them."
Actively involving kids in making the transition to healthier school menus may be the answer, she said. "This is a perfect learning opportunity. We want children to become involved in civil society, to grow up to vote and all these things, so we should be involving them in this change. We can be doing taste testing. They can create advertising for healthy food. They can analyze the nutritional impact of foods in their cafeterias. They can look at standards from different jurisdictions in class and they can even assist in monitoring the implementation of policy."

Chow was hopeful that some progress will made as a result of the September meeting between federal Health Minister Leona Aglukkaq and provincial and territorial health ministers, during which a framework for action on childhood obesity was released (www.phac-aspc.gc.ca /hp-ps/hl-mvs/framework-cadre/pdf/cco .pdf). Plans include increasing accessibility to nutritious food, taking aim at the marketing of junk food and regularly reporting on existing nutrition and physical education programs.

Other delegates, including former Ontario premier Bob Rae, spoke of the need for a national food strategy for all Canadians. The delegates said such a strategy would set standards for food sovereignty, safety and population nutrition and may provide the impetus for tighter regulation of sodium in the food supply. - Lauren Vogel, CMAJ

DOI:10.1503/cmaj.109-3718 